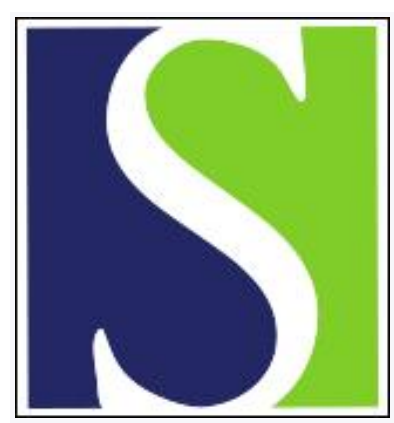

Scand J Work Environ Health 1984;10(2):71-74

https://doi.org/10.5271/sjweh.2355

Issue date: Apr 1984

Chromosome aberrations in lymphocytes of nurses handling cytostatic agents.

by Nikula E, Kiviniitty K, Leisti J, Taskinen PJ

This article in PubMed: www.ncbi.nlm.nih.gov/pubmed/6382593

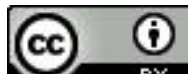




\title{
Chromosome aberrations in lymphocytes of nurses handling cytostatic agents
}

\author{
by Eeva Nikula, MSc, Kalevi Kiviniitty, PhD, Jaakko Leisti, MD, Pentti J Taskinen, MD ${ }^{1}$
}

\begin{abstract}
NIKULA E, KIVINIITTY K, LEISTI J, TASKINEN PJ. Chromosome aberrations in lymphocytes of nurses handling cytostatic agents. Scand $J$ Work Environ Health 10 (1984) 71-74. In an evaluation of the possible chromosome damage caused by cytostatic agents 11 nurses with long-term exposure to such agents were studied. Five laboratory workers and 11 hospital clerks served as referents. The number of chromosomally aberrant lymphocytes was significantly higher in the group of nurses than in the group of laboratory workers or hospital clerks. The number of chromosome-type breaks was increased significantly among the nurses as compared to the reference groups. There was no significant difference in the number of chromatid-type breaks between the groups. The observed increase in chromosome-type aberrations may have been due to long-term occupational exposure to cytostatic agents.
\end{abstract}

Key terms: chemotherapeutic drugs, chromosome damage, mutagens, occupational exposure.

Cytostatic agents have been shown to cause chromosome aberrations and sister chromatid exchanges both in vitro $(2,3,7,16,19)$ and in cells of patients after cytostatic therapy $(1,4,8,9,10,14,15,16)$.

Over the past few years attention has also been paid to the possible mutagenic effect of smaller doses on, eg, the staff of oncologic units, who must increasingly handle cytostatic agents $(6,18,20)$. An increased frequency of both sister chromatid exchanges and chromosome breaks has been observed in the cultured lymphocytes of such nursing staff $(18,20)$.

To evaluate the possible occupational health hazard of handling cytostatic agents, we have studied chromosome aberrations among nurses of the oncologic units of the Oulu University Central Hospital. The study was prompted by the appearance of clinical signs which were suspected to arise from the nurses' exposure to cytostatic agents. These nurses had been working daily on the preparation and administration of cytostatics for many years without any special protection.

\section{Material and methods}

\section{Case material}

Lymphocyte chromosomes were analyzed from 11 nurses who had been handling cytostatic agents

\footnotetext{
1 Department of Radiotherapy and Department of Clinical Genetics, Oulu University Central Hospital, SF-90220 Oulu, Finland.
}

Reprint requests to: Ms E Nikula, Department of Radiotherapy and Department of Clinical Genetics, Oulu University Central Hospital, SF-90220 Oulu, Finland. (preparation of solutions, drawing of injection infusion solutions, patient treatment) for a long period. Four of them were working in the outpatient department, and the others were in the wards.

Five laboratory workers and 11 hospital clerks, none of whom were exposed to cytostatic agents, were used as reference groups.

The estimated exposure of the 11 nurses to cytostatic agents is shown in table 1 . The mean of the estimated handling time was $2,800 \mathrm{~h}$ during a period ranging from 2.5 to 18 years.

Up until the autumn of 1979 the cytostatic agents were handled without any special protective measures. The nurses were estimated to have handled cytostatic agents $3-4 \mathrm{~h}$ daily on the same premises where they continuously worked.

During 1979-1980, three nurses developed symptoms and signs which were considered to arise from the prolonged handling of cytostatic agents. These nurses have not been handling cytostatic agents since that time (persons 9-11 in table 1).

After this episode the use of protective gloves, masks, and a fume cupboard was initiated, and the place of handling was isolated. A periodic system of handling was adopted in such a manner that the outpatient nurses handled cytostatic agents for $8 \mathrm{~h}$ a day for one week every third week (persons $1-3$ in table 1) and the ward nurses for $8 \mathrm{~h}$ a day for one week every third month (persons $4-8$ in table 1). By the time the blood sample was drawn, the nurses had been using protective precautions for about one year. According to the information given by the nurses, the five most frequently used cytostatic agents were cyclophosphamide, doxorubicin, vincristine, 5-flu- 
Table 1. Exposure of the oncologic nurses to cytostatic agents.

\begin{tabular}{|c|c|c|c|c|c|}
\hline \multirow[t]{2}{*}{ Person ${ }^{a}$} & \multirow{2}{*}{$\begin{array}{c}\text { Age } \\
\text { (years) }\end{array}$} & \multirow{2}{*}{$\begin{array}{l}\text { Length of } \\
\text { employment } \\
\text { at hospital (years) }\end{array}$} & \multicolumn{2}{|c|}{$\begin{array}{l}\text { Estimated time of handling } \\
\text { cytostatic agents }\end{array}$} & \multirow{2}{*}{$\begin{array}{c}\text { Time between } \\
\text { latest exposure } \\
\text { and blood sample (months }\end{array}$} \\
\hline & & & Hours & Years & \\
\hline 1 & 38 & 15 & 3,600 & 8.0 & 1 \\
\hline 2 & 36 & 6 & 1,800 & 4.0 & 1 \\
\hline 3 & 36 & 12 & 3,000 & 7.0 & 1 \\
\hline 4 & 41 & 18 & 2,900 & 7.0 & 3 \\
\hline 5 & 27 & 4 & 900 & 2.5 & 3 \\
\hline 6 & 35 & 14 & 4,000 & 9.0 & 3 \\
\hline 7 & 47 & 15 & 3,200 & 8.5 & 3 \\
\hline 8 & 39 & 10 & 1,000 & 10.0 & 3 \\
\hline 9 & 40 & 15 & 3,100 & 7.0 & 24 \\
\hline 10 & 43 & 21 & 4,000 & 10.0 & 17 \\
\hline 11 & 36 & 12 & 3,600 & 8.0 & 12 \\
\hline
\end{tabular}

a Persons 1 to 3 are outpatient nurses, persons 4 to 8 ward nurses, and persons 9 to 11 nurses who have not been handling cytostatic agents since 1979-1980 because of clinical consequences (a child born with hepatitis, changes in laboratory values of liver function tests and hepatitis).

Table 2. Absolute number of structural chromosome aberrations observed in the lymphocytes of the oncologic nurses (group I), laboratory workers (group II), and hospital clerks (group III).

\begin{tabular}{|c|c|c|c|c|c|c|c|c|c|c|c|c|c|}
\hline \multirow[b]{2}{*}{ Group } & \multirow{2}{*}{$\begin{array}{l}\text { Number } \\
\text { of } \\
\text { persons }\end{array}$} & \multirow{2}{*}{$\begin{array}{l}\text { Mean } \\
\text { age } \\
\text { (years) }\end{array}$} & \multirow{2}{*}{$\begin{array}{l}\text { Number } \\
\text { of ana- } \\
\text { lyzed } \\
\text { cells }\end{array}$} & \multicolumn{2}{|c|}{ Aberrant cells } & \multicolumn{5}{|c|}{ Chromosome-type aberrations } & \multicolumn{3}{|c|}{ Chromatid-type aberrations } \\
\hline & & & & $\begin{array}{l}\text { Includ- } \\
\text { ing } \\
\text { gaps }\end{array}$ & $\begin{array}{l}\text { Exclud- } \\
\text { ing } \\
\text { gaps }\end{array}$ & Isogaps & $\begin{array}{l}\text { Isochro- } \\
\text { matid } \\
\text { breaks }\end{array}$ & $\begin{array}{c}\text { Acentric } \\
\text { frag- } \\
\text { ments }\end{array}$ & Minutes & $\mathrm{CSE}^{\mathrm{b}}$ & Gaps & $\begin{array}{l}\text { Chro- } \\
\text { matid } \\
\text { breaks }\end{array}$ & $\begin{array}{l}\text { Chromatid- } \\
\text { type rear- } \\
\text { rangements }\end{array}$ \\
\hline 1 & 11 & 38 & 5,629 & 354 & 223 & 22 & 20 & 142 & 17 & 31 & 134 & 48 & 3 \\
\hline II & 5 & 31 & 2,670 & 103 & 58 & 4 & 6 & 23 & 4 & 12 & 46 & 19 & 1 \\
\hline III & 11 & 30 & 5,208 & 239 & 97 & 15 & 5 & 37 & 14 & 8 & 142 & 37 & 2 \\
\hline
\end{tabular}

a Excluding cells with gaps only.

b CSE = dicentric, ring chromosomes and other chromosome-type rearrangements.

Table 3. Number of aberrant cells and chromosome- and chromatid-type breaks per 100 analyzed cells in the three study groups. (I = oncologic nurses, II = laboratory workers, III = hospital clerks, and SE = standard error)

\begin{tabular}{|c|c|c|c|c|c|c|c|c|c|c|c|c|}
\hline \multirow{3}{*}{ Group } & \multicolumn{4}{|c|}{ Aberrant cells } & \multicolumn{4}{|c|}{ Chromosome-type breaks } & \multicolumn{4}{|c|}{ Chromatid-type breaks } \\
\hline & \multicolumn{2}{|c|}{ Including gaps } & \multicolumn{2}{|c|}{ Excluding gaps ${ }^{a}$} & \multicolumn{2}{|c|}{ Including gaps } & \multicolumn{2}{|c|}{ Excluding gaps ${ }^{a}$} & \multicolumn{2}{|c|}{ Including gaps } & \multicolumn{2}{|c|}{ Excluding gaps } \\
\hline & Mean & SE & Mean & SE & Mean & SE & Mean & SE & Mean & SE & Mean & SE \\
\hline 1 & 6.3 & 0.7 & 4.0 & 0.4 & 4.6 & 0.4 & 4.2 & 0.5 & 3.3 & 0.5 & 1.0 & 0.4 \\
\hline II & 3.9 & 0.9 & 2.2 & 0.3 & 2.3 & 0.2 & 2.1 & 0.1 & 2.5 & 0.8 & 0.8 & 0.2 \\
\hline III & 4.6 & 0.9 & 1.9 & 0.4 & 1.7 & 0.3 & 1.6 & 0.3 & 3.5 & 0.9 & 0.8 & 0.2 \\
\hline
\end{tabular}

a Excluding cells with gaps only.

Table 4. Number of aberrant cells and chromosome- and chromatid-type breaks per 100 analyzed cells in the three subgroups of oncologic nurses.

\begin{tabular}{|c|c|c|c|c|c|c|c|}
\hline \multirow{2}{*}{ Group } & \multirow{2}{*}{$\begin{array}{l}\text { Number of } \\
\text { analyzed } \\
\text { cells }\end{array}$} & \multicolumn{2}{|c|}{$\begin{array}{l}\text { Aberrant } \\
\text { cells }\end{array}$} & \multicolumn{2}{|c|}{$\begin{array}{l}\text { Chromosome-type } \\
\text { breaks }\end{array}$} & \multicolumn{2}{|c|}{$\begin{array}{c}\text { Chromatid-type } \\
\text { breaks }\end{array}$} \\
\hline & & $\begin{array}{l}\text { Including } \\
\text { gaps }\end{array}$ & $\begin{array}{c}\text { Excluding } \\
\text { gaps }^{\mathrm{a}}\end{array}$ & $\begin{array}{l}\text { Including } \\
\text { gaps }\end{array}$ & $\begin{array}{c}\text { Excluding } \\
\text { gaps }\end{array}$ & $\begin{array}{c}\text { Including } \\
\text { gaps }\end{array}$ & $\begin{array}{l}\text { Excluding } \\
\text { gaps }^{\mathrm{a}}\end{array}$ \\
\hline $\begin{array}{l}\text { Outpatient nurses } \\
\text { Ward nurses } \\
\text { Nurses no longer handling }\end{array}$ & $\begin{array}{l}1,627 \\
2,441\end{array}$ & $\begin{array}{l}5.5 \\
7.1\end{array}$ & $\begin{array}{l}4.0 \\
4.4\end{array}$ & $\begin{array}{l}5.8 \\
4.7\end{array}$ & $\begin{array}{l}5.8 \\
4.2\end{array}$ & $\begin{array}{l}2.2 \\
3.8\end{array}$ & $\begin{array}{l}0.8 \\
1.1\end{array}$ \\
\hline cytostatics & 1,561 & 5.9 & 3.3 & 3.3 & 2.8 & 3.6 & 0.9 \\
\hline
\end{tabular}

a Excluding cells with gaps only. 
orouracil, DTIC (dimethyltriazenoimidatsolcarboxamide), and, previously, methotrexate.

All the individuals were interviewed about their daily habits and other possible factors affecting the results of the chromosome analysis. All but two (persons $10 \& 11$ in table 1) of the subjects were healthy and free of any viral disease at the time the blood sample was drawn. All the subjects were nonsmokers, except three hospital clerks, who smoked $1-10$ cigarettes daily. The number of nurses and hospital clerks subjected to diagnostic X-ray examinations was about equal with no reported exposure among the laboratory workers. Three oncologic nurses had been working occasionally with diagnostic X-ray equipment prior to 1972 . None had been receiving any therapeutic irradiation.

All laboratory workers and one hospital clerk reported exposure to chemicals, especially to organic solvents. An occasional use of drugs was reported by two nurses and two hospital clerks. One of the nurses (person 11 in table 1) received Prednisone $(5-15 \mathrm{mg}$ daily) and three clerks were on birth control pills during the study.

\section{Cytogenetic methods}

Whole blood cultures were made according to standard techniques. Each culture containing $4.0 \mathrm{ml}$ of Minimum Essential Medium - Eagle (Gibco-Europe, United Kingdom) with L-glutamine ( $2 \mathrm{mM}$, GibcoEurope, United Kingdom) and penicillin-streptomycin ( $50 \mathrm{IU} / \mathrm{ml}$, Gibco-Europe, United Kingdom) and $20 \%$ inactivated male human $\mathrm{ABO}$ serum (Finnish Red Cross, Helsinki, Finland), $0.2 \mathrm{ml}$ of phytohemagglutinin-P (Difco, Detroit, Michigan, United States), and $0.4 \mathrm{ml}$ of heparinized blood was incubated at $37^{\circ} \mathrm{C}$ in a closed system for $48 \mathrm{~h}$. One hour after the addition of Colcemid solution $(0.1 \mu \mathrm{g} / \mathrm{ml}$, Giba, Milano, Italy) the cultures were harvested by centrifugation, 15 -min hypotonic treatment $(0.075 \mathrm{M}$ potassium chloride), and three or four periods of fixation (methanol-acetic acid $3: 1$ ). The air-dried chromosome preparations were stained for $7 \mathrm{~min}$ in $10 \%$ Giemsa (Merck, Darmstadt, Federal Republic of Germany) diluted in Sörensen buffer, pH 7.0.

From each individual, with the exception of two, a minimum of 500 euploid or hyperploid metaphases was analyzed for chromosome aberrations. The analyses were done by two persons on coded slides, and all aberrations were checked by one of them. The structural aberrations were classified as chromatidtype or chromosome-type changes (12). A break was classified as a chromatid break when the distal segment of the chromatid was clearly separated; otherwise it was considered a gap.

An isochromatid break was classified as an acentric fragment when it appeared completely separated from other chromosomes and was additional to the normal diploid chromosome number.
Isogaps, isochromatid breaks, acentric fragments, and minutes were counted as one, while dicentric, ring chromosomes and other chromosome types of rearrangements were counted as two chromosometype breaks. Gaps and chromatid breaks were counted as one and chromatid-type rearrangements as two chromatid-type breaks.

The one-sided Mann-Whitney U-test was used to test the statistical differences between the groups.

\section{Results}

The cytogenetic results from the three study groups are presented in tables 2 and 3.

The total number of aberrant cells, including gaps in the group of the oncologic nurses, was almost significantly ( $p \leq 0.05$ ) greater than that of the other two groups. The difference was significant $(p \leq 0.01)$ when cells with gaps only were excluded (table 3 ).

The number of chromosome-type breaks was also significantly greater $(p \leq 0.01)$ in the group of oncologic nurses than in the other two groups. This phenomenon was mainly due to a greater number of acentric fragments in the group of nurses (table 2). The incidence of acentric fragments was $2.5 \%$ for the nurses, $0.9 \%$ for the laboratory workers, and $0.7 \%$ for the hospital clerks.

The number of chromatid-type breaks did not show any statistically significant differences between the groups.

The number of chromosome-type breaks was greatest in the outpatient nurses, who had handled cytostatic agents the most frequently (table 4 ). However the differences between the three subgroups of oncologic nurses were not significant.

Marked interindividual variation could be seen in the different study groups. Hence no correlation was found between the estimated accumulated time of exposure and the frequency of breaks in individual cases.

\section{Discussion}

To our knowledge, only two studies have thus far been published on chromosome damage in nursing staff handling cytostatic agents. In one of the two the frequency of sister chromatid exchanges was shown to have increased significantly (18), and in the other an increased number of chromosome gaps was also observed (20).

Our results show that chromosome-type breaks and aberrant cells may also be found in excess among nurses handling cytostatic agents.

The clastogenic effect of several cytostatic agents has been documented $(2,4,7,15,19)$. The present results, together with those of previous studies, suggest that even seemingly small doses can change genetic material.

In the interpretation of chromosome changes numerous technical, environmental, and individual fac- 
tors have to be taken into consideration. In the present study the known environmental factors, such as radiation, viral diseases, chemicals, drugs, and smoking $(7,13)$, were evaluated carefully. With respect to these factors there were no clear group differences which could explain the greater number of chromosome breaks in the oncologic nurses. Ionizing radiation is known to induce chromosome breaks. Three oncologic nurses had been working with diagnostic $\mathrm{X}$-ray equipment prior to 1972 . In one of them $2.1 \%$ of all the cells were tetraploid cells, and in two of the tetraploid cells a total of nine dicentric chromosomes were observed. However almost ten years had elapsed since a possible exposure to the radiation, and it is improbable that the chromosome changes would have been caused purely by radiation.

A correlation between age and structural chromosome aberrations, as well as age and the retention of chromosome damage caused by mutagens, has been reported $(5,11)$. In the present study the mean age of the oncologic nurses was only slightly higher than that of the other groups, and therefore age has probably not affected the results.

It is possible that the chromosome breaks and aberrant cells found in peripheral lymphocytes of the oncologic nurses have accumulated during the long period when the nurses handled cytostatic agents without protection. The accumulation may be related to the long half-time of peripheral lymphocytes, which is estimated to be three to four years (17). This assumption is supported by the observation that the nurses who had not been handling cytostatic agents for the past one or two years prior to the sampling had the smallest number of chromosome breaks (table 4). These were the nurses who had been suspected of having suffered clinical consequences from exposure to cytostatic agents.

Despite the limitations of the cytogenetic methods in mutagenicity testing, our findings indicate that the occupational exposure of oncologic nurses to cytostatic agents may cause an increase in chromosome aberrations. Therefore protective measures and care in the handling must be further emphasized. The effectiveness of protective measures should also be evaluated.

\section{Acknowledgments}

The cooperation of the nurses, the laboratory personnel, and the clerks and the skillful and responsible technical assistance of Ms P Ruokojärvi are gratefully acknowledged.

\section{References}

1. Aronson MM, Miller RC, Hill RB, Nichols WW, Meadows AT. Acute and long-term cytogenetic effects of treatment in childhood cancer: Sister-chromatid exchanges and chromosome aberrations. Mutat Res 92 (1982) 291-307.

2. Au W, Sokova OI, Kopnin B, Arrighi FF. Cytogenetic toxicity of cyclophosphamide and its metabolites in vitro. Cytogenet Cell Genet 26 (1980) 108-116.

3. Banerjee A, Benedict WF. Production of sister-chromatid exchanges by various cancer chemotherapeutic agents. Cancer Res 39 (1979) 797-799.

4. Dobos M, Schuler D, Fekete G. Cyclophosphamideinduced chromosomal aberrations in nontumorous patients. Hum Genet 22 (1974) 221-227.

5. Evans HJ, Bucton KE, Hamilton GE, Carothers A. Radiation induced chromosome aberrations in nucleardockyard workers. Nature 277 (1979) 531-534.

6. Falck K, Gröhn P, Sorsa M, Vainio H, Heinonen E, Holsti LR. Mutagenicity in urine of nurses handling cytostatic drugs. Lancet 2 (1979) 1250-1251.

7. Gebhart E. Sister chromatid exchanges (SCE) and structural chromosome aberration in mutagenicity testing. Hum Genet 58 (1981) 235-254.

8. Gebhart E, Lösing J, Wopfner F. Chromosome studies on lymphocytes of patients under cytostatic therapy: I Conventional chromosome studies in cytostatic interval therapy. Hum Genet 55 (1980) 53-63.

9. Gebhart E, Windolph B, Wopfner F. Chromosome studies on lymphocytes of patients under cytostatic therapy: II Studies using the BUDR-labelling technique in cytostatic interval therapy. Hum Genet 56 (1980) $157-167$

10. Harrod EK, Cortner JA. Prolonged survival of lymphocytes with chromosomal defects in children treated with 1,3-bis (2-chloroethyl)-1-nitrosourea. J Natl Cancer Inst 40 (1968) $269-279$.

11. Hedner K, Hönstedt B, Kolnig A-M, Mark-Vendel E, Strömbeck B, Mitelman F. Sister chromatid exchanges and structural chromosome aberrations in relation to age and sex. Hum Genet 62 (1982) 305-309.

12. International system for human cytogenetic nomenclature. ISCN (1978). Cytogenet Cell Genet 21 (1978) 309-404.

13. Lloyd DC, Purrott RJ, Reeder EJ. The incidence of unstable chromosome aberrations in peripheral blood lymphocytes from unirradiated and occupationally exposed people. Mutat Res 72 (1980) 523-532.

14. Miller RC, Hill RB, Nichols WW, Meadows AT. Acute and long-term cytogenetic effects of childhood cancer chemotherapy and radiotherapy. Cancer Res 38 (1978) $3241-3246$.

15. Musilova J, Michaloya K, Urban J. Sister-chromatid exchanges and chromosomal breakage in patients treated with cytostatics. Mutat Res 67 (1979) 289-294.

16. Nevstad NP. Sister chromatid exchanges and chromosomal aberrations induced in human lymphocytes by the cytostatic drug adriamycin in vivo and in vitro. Mutat Res 57 (1978) 253-258.

17. Norman A, Sasaki MS, Ottoman RE, Fingerhut AG. Lymphocyte lifetime in women. Science 147 (1965) 745.

18. Norppa H, Sorsa M, Vainio H, Gröhn P, Heinonen E, Holsti L, Nordman E. Increased sister chromatid exchange frequencies in lymphocytes of nurses handling cytostatic drugs. Scand J Work Environ Health 6 (1980) 299-301.

19. Slacik-Erben $R$, Obe $G$. The effect of sodium fluoride on DNA synthesis, mitotic indices and chromosomal aberrations in human leukocytes treated with trenimon in vitro. Mutat Res 37 (1976) 253-266.

20. Waksvik $\mathrm{H}$, Klepp O, Brogger A. Chromosome analyses of nurses handling cytostatic agents. Cancer Treat Rep 65 (1981) 607-610.

Received for publication: 25 October 1983 